\title{
O DEVER INSTRUMENTAL INFORMATIZADO E A DENÚNCIA ESPONTÂNEA
}

\author{
The duty computerized instrumental and voluntary disclosure
}

\section{Andreia Fogaça Maricato}

Mestre, Especialista e Doutoranda em Direito Tributário pela PUC-SP. Professora no lbet de São Paulo e Coordenadora do Ibet de São José dos Campos.

Recebido em: 04.07.2012

Aprovado em: 22.08.2012

ÁrEA Do DIREITO: Tributário

Resumo: Nosso objeto de estudo compõe-se na análise das mudanças trazidas com a informatização fiscal nos deveres instrumentais e quais seus impactos no instituto da denúncia espontânea, tema que gera ainda muita discussão na doutrina e na jurisprudência. Para isto, tomamos o direito como um conjunto de normas jurídicas válidas, que se materializam na forma de enunciados prescritivos. 0 modo de nos aproximarmos do direito é interpretando tais enunciados, ou seja, construindo o sentido dos textos. Faremos uma interpretação sistemática dos enunciados que prescrevem os deveres instrumentais e suas sanções, para mostrar como se dá a construção das respectivas normas jurídicas. 0 método adotado é o dogmático, e a técnica é a hermenêutica-analítica, procurando deixar o trabalho situado na linha doutrinária denominada consctrutivismo lógico-semântico.
ABSTRACT: Our object of study consists in analyzing the changes brought about by the computerization tax obligations in which instruments and their impact on the institution of voluntary disclosure, an issue that still generates a lot of discussion on the doctrine and jurisprudence. For this, we take the law as a set of valid legal norms, which materialize in the form of prescriptive statements. The way to approach the right is playing such statements, i.e., constructing the meaning of texts. We will make a systematic interpretation of statements which prescribe the duties and their instrumental sanctions, to show how is the construction of the respective law. The method adopted is the dogmatic, and the hermeneutic-analytical technique, trying to leave work situated within the doctrinal consctrutivismo called logical-semantic. 
Palavras-chave: Dever instrumental - Informatização fiscal - Denúncia espontânea.
KeYwords: Duty vehicle - Tax computerization Voluntary disclosure.

SumÁRıo: 1. Introdução - 2. Delimitação do objeto - 3. Dever instrumental informatizado - 4. Denúncia espontânea - 5. Impactos da informatização na denúncia espontânea - 6. Conclusões - 7. Referências bibliográficas.

\section{INTRODUÇÃO}

O tema "deveres instrumentais", por não ser tão explorado, levanta inúmeros conflitos, propiciando o surgimento de questões bastante atuais e polêmicas. Por se tratar de assunto de alta complexidade, detentor de muitas particularidades, as questões que envolvem o assunto ora proposto ainda merecem a atenção dogmática do direito.

A tecnologia chegou aos deveres instrumentais, formando um sistema de cruzamento de dados, via digital. Atualmente, mais da metade das declarações enviadas ao fisco são entregues via digital. Isto significa que, em pouco tempo, todos os documentos serão eletrônicos e a forma de fiscalização dos tributos será totalmente digital.

Tudo isto porque a informatização fiscal tem como objetivo facilitar a cobrança de tributos e reduzir o custo operacional do uso de pessoas e arquivos físicos que dependam de papel, além de diminuir a sonegação.

A informatização fiscal gera a necessidade de revisão teórica de vários institutos jurídicos do direito tributário; em especial, analisaremos o impacto da informatização fiscal nos deveres instrumentais, implicando mudanças sistemáticas no lançamento tributário.

Em paralelo, estudaremos a denúncia espontânea, a que se refere o art. 138 do $\mathrm{CTN}$, que, assim como vários temas do direito tributário, também suscitou controvérsias, sendo seu texto aberto a inúmeras interpretações, muitas vezes conflitantes.

Tomamos por pressuposto que a interpretação mais adequada da norma jurídica é aquela que melhor garante os valores nela inseridos. Deste modo, entendemos que o enunciado do art. 138 do CTN tem como objetivo trazer o infrator da lei tributária de volta para uma situação de regularidade. Para isto, analisamos os aspectos mais polêmicos do enunciado prescritivo.

A principal questão que provoca divergências entre o fisco, doutrinadores e tribunais é a que diz respeito ao alcance do art. 138 do CTN; delimitar-nos- 
-emos ao fato de que o descumprimento do dever instrumental (obrigação acessória) informatizado possibilitaria ao contribuinte se beneficiar do instituto da denúncia espontânea, afastando-se para além das multas de ofício, de mora e isoladas.

Para isto, optamos por fazer neste trabalho, num primeiro plano, investigação semântica sobre os conceitos dos deveres instrumentais informatizados, em seguida da denúncia espontânea, para, posteriormente, analisar as hipóteses de exclusão das multas: de ofício, de mora e isoladas, quando do descumprimento dos deveres instrumentais informatizados, uma vez que a informatização altera toda a sistemática do lançamento atual, criando indagações ainda não regulamentadas.

\section{DeliMitaçÃO DO OBJETO}

Faremos um corte metodológico na apreensão do processo de conhecimento. Na medida em que não pretendemos tratá-lo como objeto autônomo de investigação, limitar-nos-emos a explicar o papel desempenhado pela linguagem dentro da operação cognitiva, mostrando em que medida a linguagem, enquanto manifestação cultural, influencia a teoria do conhecimento.

Firmada a premissa que o conhecimento se opera mediante construção linguística, podemos afirmar que não existe fato antes da interpretação. É mediante interpretações, construções de sentido e significações que o homem chega aos eventos, aos acontecimentos do mundo circundante, sendo imprescindível a existência de um corpo linguístico para fazer a conexão entre o homem e a realidade. Todavia, isto não significa que inexiste qualquer objeto físico quando não houver linguagem. O que estamos falando é que só teremos acesso às coisas que existem no mundo por meio da linguagem. Como leciona Paulo de Barros Carvalho:" "conheço determinado objeto na medida em que posso expedir enunciado sobre ele, de tal arte que o conhecimento se apresenta pela linguagem, mediante proposições descritivas ou indicativas". O conhecimento pressupõe a existência de linguagem, cria ou constitui a realidade, sendo impossível conhecer as coisas como elas se apresentam fisicamente, fora dos discursos a que elas se referem.

Por isto, o mundo não é um conjunto de coisas que primeiro se apresentam e, depois, são nomeadas ou representadas por uma linguagem. Isso que cha-

1. Direito tributário: fundamentos jurídicos da incidência. 2. ed. São Paulo: Saraiva, 2008. p. 110. 
mamos de mundo nada mais é que uma interpretação, sem a qual nada faria sentido. ${ }^{2}$

Adotada a posição de que o conhecimento se opera mediante construção linguística, temos que a linguagem não só fala do objeto (ciência do direito - metalinguagem), como participa de sua constituição (direito positivo - linguagem - objeto). Assim, não há manifestação do direito sem uma linguagem, idiomática ou não, que lhe sirva de veículo de expressão, aqui tomado na sua acepção normativa, como conjunto de normas jurídicas válidas vigentes num sistema, em um determinado momento histórico.

\section{DeVER INSTRUMENTAL INFORMATIZADO}

Código Tributário Nacional denomina os vínculos jurídicos que não apresentam cunho patrimonial de obrigações acessórias. Entretanto, adotamos a terminologia "deveres instrumentais" para as chamadas "obrigações acessórias", pois, como imposições de um fazer ou de um não fazer o dever instrumental não pode caracterizar uma obrigação, já que é despido de conteúdo de cunho patrimonial.

Por serem verdadeiros deveres, não são tais obrigações acessórias, porque a administração tributária fará uso do cumprimento dos deveres impostos aos contribuintes para aferir se houve, ou não, a concreção da hipótese de incidência da norma de tributação. No caso da comprovação da não ocorrência do fato jurídico tributário e a não instauração do vínculo obrigacional (obrigação tributária principal), diversos deveres foram cumpridos (entrega de documentos, preenchimentos de guias, declarações etc.), mas nenhuma relação jurídica de cunho patrimonial se instaurou. Portanto, as impropriamente denominadas obrigações acessórias são vínculos jurídicos que não apresentam cunho patrimonial e têm caráter instrumental, cujo objetivo é assegurar a efetividade da arrecadação e a fiscalização dos tributos.

Portanto, os deveres instrumentais constituem-se, sim, em dever, porque decorrem da lei e são instrumentais, por terem a função de operacionalizar a regra matriz de incidência tributária, servindo como instrumento da atividade de arrecadação e fiscalização dos tributos. ${ }^{3}$

Neste contexto, os deveres instrumentais cumprem um importante papel na implantação do tributo. Por se tratar de um dever de fazer ou não fazer,

2. Tomé, Fabiana Del Padre. A prova no direito tributário. São Paulo: Noeses, 2005. p. 5.

3. Maricato, Andréia Fogaça. Deveres instrumentais: regra matriz e sanção. Dissertação de Mestrado, São Paulo, PUC, 2009, p. 128. 
a sua observância depende de documentação, em linguagem competente, de tudo o que diz respeito ao tributo.

Os deveres instrumentais regulam a atuação do contribuinte, pois são tidos como normas de conduta. Paulo de Barros Carvalho ${ }^{4}$ os define como sendo os elos concebidos visando ao aparecimento de deveres jurídicos, que os súditos do Estado, sujeito ativo (Fisco), têm a obrigação de respeitar, no sentido de imprimir efeitos práticos à percepção dos tributos. Em suas palavras:

"São liames concebidos para produzirem o aparecimento dos deveres jurídicos, que os súditos do Estado hão de observar, no sentido de imprimir efeitos práticos à percepção dos tributos. É dever de todos prestar informações ao Poder Público, executando certos atos e tomando determinadas providências de interesse geral, para que a disciplina do relacionamento comunitário e a administração da ordem pública ganhem dimensões reais concretas. Nessa direção, o cumprimento de incontáveis deveres é exigido de todas as pessoas, no plano sanitário, urbanístico, agrário, de trânsito etc., e também, no que entende com a atividade tributante que o Estado exerce."

Deste modo, exceto a obrigação de levar certa quantia em dinheiro aos cofres públicos, advinda da relação jurídica tributária em sentido estrito, estabelecendo o vínculo entre sujeito ativo (Fisco) e o sujeito passivo (contribuinte), e, por conseguinte, o direito subjetivo ao Estado, por meio da Administração. Todos os demais deveres impostos a esse mesmo sujeito passivo, defronte ao tributo instituído, com a inerente característica da impossibilidade de mensuração econômica, de cunho administrativo, devem ser entendidos como deveres instrumentais. A causa geradora dos deveres instrumentais é a lei. Assim, ocorrida a situação descrita na norma, nasce o dever de fazer, não fazer ou tolerar, sem cunho pecuniário.

A lei tributária estabelece diversos deveres ao sujeito passivo, a fim de que constituam em linguagem competente eventos do mundo social sobre os quais o direito atua, com o objetivo de atingir seus propósitos originários, ou seja, enquanto sujeito passivo, cumpre os deveres instrumentais que lhe são impostos, relata em linguagem os eventos do mundo fenomênico, dando ao Fisco a possibilidade de constituir o fato jurídico tributário, que, sem os deveres instrumentais, muitas vezes não poderá ser constituído na forma jurídica própria.

É por meio dos deveres instrumentais que o Estado consegue fazer o controle, no que tange à observação do cumprimento das obrigações inerentes à

4. Curso de direito tributário. São Paulo: Saraiva, 2008. p. 804. 
instituição dos gravames fiscais e nos casos em que, como exemplos, temos: a expedição de notas fiscais, a prestação de informações, a escrituração de livros, o registro do papel imune, dentre outros.

O objetivo principal de tais deveres é instrumentalizar a atividade de arrecadação e a fiscalização dos tributos. São regras constituídas com a finalidade de controlar a ocorrência de fazer com que os contribuintes suportem e ajudem na fiscalização, para apurar o eventual nascimento de obrigação tributária material ou demonstrar o seu não nascimento, como nos casos de imunidade. Portanto, são medidas necessárias ao controle da ação de tributar e são dirigidas diretamente à conduta dos contribuintes ou a quem a lei determinar, impondo-lhes deveres de tomar certas medidas destinadas a possibilitar à Administração controlar o nascimento ou não do fato jurídico tributário.

Ocorrido o evento do dever instrumental no mundo fenomênico, ele só se tornará fato jurídico do dever instrumental mediante linguagem competente fornecida por meio da teoria das provas. Assim, tanto a regra matriz de incidência tributária quanto os deveres instrumentais, necessitam de uma linguagem competente que os constituam. Ou seja, a relação jurídica de conteúdo não patrimonial, determinando em seu objeto a prestação de fazer ou não fazer do dever instrumental nascerá por meio da linguagem competente.

O fato jurídico do dever instrumental para integrar o mundo jurídico necessita de sua publicação. Ou seja, não basta que exista uma lei de dever instrumental determinando em sua hipótese que "A", ao circular mercadoria, deve emitir nota fiscal.

Faz-se necessário que "A", ao circular mercadoria no mundo fenomênico, emita a nota fiscal, e, ao emiti-la, constituiu-se o fato jurídico do dever instrumental (linguagem competente). Por outro lado, se "A" realizar a operação de circular mercadoria sem a emissão da nota fiscal, não há o fato jurídico do dever instrumental; mas, se, posteriormente, o agente fiscal verificar o não cumprimento do dever instrumental no estabelecimento de "A", constituirá em linguagem competente o fato jurídico do dever instrumental com a aplicação do auto de infração e imposição de multa, pelo seu descumprimento.

Portanto, podemos afirmar que os deveres instrumentais necessitam de linguagem competente para que surtam efeitos no mundo jurídico; caso contrário, eles serão um mero evento que se perde no tempo e no espaço.

A implementação e utilização da informatização fiscal nos deveres instrumentais vêm para facilitar a identificação do valor correto do tributo devido, e, ao mesmo tempo, o fisco passa a ter condições de confrontar os dados informados pelo contribuinte com demais dados existentes e disponíveis nos sistemas digital central, dados estes, relevantes à apuração do valor correto dos tributos 
devidos, presente nos demais órgãos públicos, em outras unidades da federação, outros países ou em quaisquer lugares em que se encontrem e possam ser rastreados por um mecanismo tecnológico. ${ }^{5}$

Pode se notar que o Fisco, de porte desta tecnologia, vem utilizando diversos mecanismos tecnológicos na formatação legal dos deveres instrumentais, para fiscalização dos tributos, ocasionando diversas mudanças nas formas de constituição do crédito tributário.

Um dos instrumentos tecnológicos que vêm sendo muito utilizados pelo Fisco no dever instrumental digitalizado é o Sistema Público de Escrituração Digital - Sped; neste novo sistema, encontram-se a nota fiscal eletrônica, a escrituração fiscal digital e a escrituração contábil digital, dentre outros.

Fabiana Lopes Pinto $^{6}$ destaca que:

"Com a implementação da informatização fiscal que está sendo inserida no ordenamento jurídico, a partir do momento em que o contribuinte relatar o evento descrito no critério material, em fato social, este fato social, passará a ter relevância para mundo jurídico, isto porque ele está sendo informado ao Fisco no exato momento de seu acontecimento, muitas vezes em momentos que antecedem o próprio fato jurídico (...)."

Segundo a autora, isto significa dizer que, neste novo modelo, o fato social passa a ser uma parte do fato jurídico, visto que há informação enviada ao Fisco de forma parcelada através dos mecanismos tecnológicos. Com a soma de todas as partes do "fato" que foram ao longo do mês ou do ano (de acordo com o imposto) informados ao Fisco, chegando-se ao fato jurídico da norma.

Importante destacar que toda vez que fato social realizado pelo sujeito passivo for representado por um documento eletrônico que manda informações diretamente ao Fisco, estaremos diante de um fato social jurídico, com relevância para o mundo jurídico, diferentemente daquele fato social, irrelevante para o direito.

Assim, quando o contribuinte cumpre os deveres instrumentais, neste novo modelo tecnológico e digital, pela simples entrega das declarações, o Fisco passar a ter possibilidade de lançar de ofício, sem a necessidade de ir à empresa conferir toda a documentação, uma vez que tais documentos passarão a ser digitais e guardados no sistema do Fisco.

5. Tema tratado por Pinto, Fabiana Lopes. Informatização fiscal: o uso da tecnologia no sistema tributário nacional. Tese de Doutorado, São Paulo, PUC, 2012.

6. Pinto, Fabiana Lopes. Impacto financeiro da sonegação fiscal-penal. Disponível em: [www.lopespinto.com.br/adv/publier4.0/dados/anexos/617_4.ppt]. Acesso em: 15.02.2012. 
Seguindo este entendimento, futuramente, com alterações legislativas, poderá ter mais lançamento de declaração e lançamento de ofício do que lançamento por homologação, isto, porque as novas normas de informatização fiscal dão ao fisco as informações necessárias para lançar de ofício, identificando com precisão o fato jurídico e sua respectiva base de cálculo, de forma a tornar o valor devido inquestionável.

Neste novo sistema, a informatização fiscal pode vir a alterar a forma de lançamento, uma vez que as informações prestadas pelo contribuinte serão suficientes para que o Fisco lance de ofício, como no caso da pré-validação, para a emissão da nota fiscal eletrônica, gerada pelo contribuinte, o qual a envia para o servidor interno da Secretaria de Estado da Fazenda do Estado de origem, aguardando a pré-validação; o sistema do Fisco faz a triagem dos requisitos exigidos para a validação e, automaticamente, identifica se a NF-e será autorizada ou não. Uma vez possuídas todas as exigências para validação, o contribuinte recebe a NF-e autorizada e imprime o Danfe (recibo). Esta pré-validação pode vir a ser o lançamento de ofício. Portanto, com a evolução dos diversos mecanismos tecnológicos que vêm sendo introduzidos de forma compulsória para a entrega dos diversos deveres instrumentais de todos os tributos, é possível que, com mudanças legislativas, outros fatos informativos do contribuinte venham a viabilizar a sincronicidade total das informações necessárias à constituição do fato jurídico tributário. Isto porque, tendo o Fisco em mãos todas as informações recebidas pelos diversos fatos informativos oriundos da obrigatoriedade de qualquer dever instrumental digital (como na da emissão eletrônica de nota fiscal), poderá o Fisco lançar de ofício imediatamente pelo sistema. ${ }^{\top}$

Neste contexto, se todos os tributos passarem a ser por lançamento de ofício, poderemos, ter mudanças significativas na denúncia espontânea, visto que, em sendo todas as informações enviadas ao Fisco de forma imediata e instantânea, faz com que o ente competente (sujeito ativo) apure eventual nascimento de obrigação tributária material.

E não sendo cumprido qualquer dever instrumental, via digital, pelo contribuinte, a Administração poderá enviar a notificação do início da fiscalização on-line. Com isto, o prazo para o contribuinte regularizar suas omissões ficará limitado. Por outro lado, a denúncia espontânea, que hoje é tão discutida e limitada, poderá ser muito mais utilizada pelo contribuinte, conforme veremos no próximo item.

7. PInto, Fabiana Lopes. Informatização fiscal... cit., p. 274. 


\section{DenÚNCIA ESPONTÂNEA}

$\mathrm{O}$ art. 138 do CTN prescreve o instituto da denúncia espontânea do direito tributário brasileiro, impedindo que a constituição do descumprimento de um dever seja concretizado em nível individual e concreto pelo agente competente, assim disposto:

“Art. 138. A responsabilidade é excluída pela denúncia espontânea da infração, acompanhada, se for o caso, do pagamento do tributo devido e dos juros de mora, ou do depósito da importância arbitrada pela autoridade administrativa, quando o montante do tributo dependa de apuração.

Parágrafo único. Não se considera espontânea a denúncia apresentada após o início de qualquer procedimento administrativo ou medida de fiscalização, relacionados com a infração."

Como se vê, o art. 138 do CTN prescreve a possibilidade de exclusão da responsabilidade pela denúncia espontânea da infração, nos casos do pagamento do tributo devido e dos juros de mora, ou do depósito da importância arbitrada pela autoridade administrativa, quando o montante do tributo depender de apuração. Neste sentido, a denúncia espontânea é aquela apresentada antes do início de qualquer procedimento administrativo ou medida de fiscalização, relacionados com a infração.

Portanto, é espontânea, a denúncia da infração cometida pelo sujeito passivo, antes da existência de procedimento administrativo ou medida de fiscalização, relacionados com a infração, da qual o sujeito passivo tenha sido regularmente notificado. Ou seja, se o Fisco houver dado ciência ao sujeito passivo quanto ao início de qualquer procedimento fiscal relacionado com a infração a ser denunciada, fica afastada a possibilidade da denúncia espontânea. Por outro lado, se a infração se refere a matéria estranha àquela objeto da fiscalização ou do procedimento administrativo já iniciado, é possível a sua denúncia espontânea.

A denúncia espontânea no direito tributário brasileiro é mecanismo normativo que permite ao sujeito passivo tributário, mesmo diante de um evento moratório, evitar que o fato moratório seja constituído pelo sujeito competente e, portanto, impedir que a constituição do descumprimento de um dever seja concretizada em nível individual e concreto.

Dessa forma, quando o sujeito passivo toma a iniciativa de cumprir a conduta prevista em norma tributária, corrigindo informações imprescindíveis para o Fisco constituir o crédito tributário, nas hipóteses de lançamento originariamente de ofício, ou quando o próprio contribuinte constitui o crédito tributário, naquelas hipóteses em que o Código Tributário Nacional lhe atribui 
a competência, originalmente, para realizar o chamado lançamento por homologação (art. 150 do CTN).

A denúncia espontânea constitui-se em instrumento normativo hábil a mutilar os efeitos jurídicos da mora no direito tributário.

Muito se discute sobre as hipóteses de cabimento da denúncia espontânea, em especial, nos tributos sujeitos ao lançamento por homologação e nas obrigações acessórias autônomas, o STJ firmou o seguinte entendimento:

Súmula 360 do STJ: "O benefício da denúncia espontânea não se aplica aos tributos sujeitos a lançamento por homologação regularmente declarados, mas pagos a destempo".

E mais, é categórico em proibir o instituto da denúncia espontânea nas chamadas obrigações acessórias autônomas, conforme demonstrado nos seguintes julgados:

"Processo civil. Denúncia espontânea. Obrigação acessória. Multa administrativa. Pretensão já colhida pelo acórdão recorrido. Falta de interesse processual.

1. Na origem, cuida-se de mandado de segurança impetrado contra ato do delegado da Receita Federal do Brasil, no qual se pleiteia o não pagamento das penalidades pecuniárias (multas), em razão da não entrega das Declarações de Imposto Retido na Fonte (Dirf's) dos anos de 1994 e 1997.

2. Segundo orientação firmada nesta Corte, 'a denúncia espontânea não tem o condão de afastar a multa decorrente do atraso na entrega da declaração de rendimentos, uma vez que os efeitos do art. 138 do CTN não se estendem às obrigações acessórias autônomas' (AgRg no AREsp 11.340/SC, 2. ${ }^{\mathrm{a}}$ T., j. 13.09.2011, rel. Min. Castro Meira, DJe 27.09.2011).

3. A Corte de origem reconheceu que é 'legítima a exigência da multa administrativa', afastando a aplicação da denúncia espontânea. Assim, as alegações no sentido que não ocorreu denúncia espontânea em relação à multa administrativa é infundada, pois tal pretensão já foi acolhida pela Corte Regional, revelando-se, portanto, a falta de interesse recursal da recorrente. Agravo regimental improvido" (AgRg no REsp 1.279.038/MG, 2. ${ }^{a}$ T., Min. Humberto Martins, DJe 09.02.2012) (grifo nosso).

"Processual civil. Embargos de declaração. Existência de contradição e erro material no acórdão. Correção. Pagamento integral do débito. Multa. Denúncia espontânea. Inaplicabilidade.

1. Os embargantes confessam que efetivaram o pagamento do tributo após o vencimento, embora sem pressão do Fisco. Tal circunstância é suficiente para que não seja aplicada a denúncia espontânea. 
2. A configuração da 'denúncia espontânea', como consagrada no art. 138 do CTN não tem a elasticidade pretendida, deixando sem punição as infrações administrativas pelo atraso no cumprimento das obrigações fiscais. A extemporaneidade no pagamento do tributo é considerada como sendo o descumprimento, no prazo fixado pela norma, de uma atividade fiscal exigida do contribuinte. É regra de conduta formal que não se confunde com o não pagamento do tributo, nem com as multas decorrentes por tal procedimento.

3. As responsabilidades acessórias autônomas, sem qualquer vínculo direto com a existência do fato gerador do tributo, não estão alcançadas pelo art. 138 do CTN. Precedentes.

4. Não há denúncia espontânea quando o crédito tributário em favor da Fazenda Pública encontra-se devidamente constituído por autolançamento e é pago após o vencimento.

5. Inexistência de parcelamento, na hipótese, que se reconhece, com a sua correção.

6. Embargos acolhidos, porém, sem efeitos modificativos. Acórdão mantido.”

Nos referidos julgados os Ministros, por unanimidade acolheram os embargos de declaração, sem efeitos modificativos, nos termos do voto do Sr. Ministro relator. Os Srs. Ministros Francisco Falcão, Luiz Fux, Teori Albino Zavascki e Denise Arruda votaram com o Sr. Ministro relator.

Em seu relatório, o Min. José Delgado destaca que nos embargos de declaração interpostos foi apontando a existência de erro material, assim transcrito:

"A parte embargante, sustenta que:

a) o decisum embargado julgou o caso dos autos como se tratasse de hipótese de pagamento parcelado de débitos em atraso, quando, na verdade, não é o caso de parcelamento, mas, sim de pagamento espontâneo integral, visto que a fundamentação contida no acórdão impugnado destina-se aos casos em que a denúncia espontânea é descaracterizada pelo parcelamento, o que não é o caso sub examine;

b) os argumentos utilizados, portanto, não se aplicam aos presentes autos, até mesmo porque é assente nesta Corte que o pagamento integral caracteriza denúncia espontânea e enseja a incidência do art. 138 do CTN.

Requer, por fim, seja sanado o erro material existente para determinar a aplicação do art. 138 do CTN, já que todos os requisitos para configuração da denúncia espontânea estão presentes.

Voto do Ministro

"A decisão hostilizada tem dois fundamentos: 
a) a denúncia espontânea não se aplica para os casos de tributos vencidos e pagos com atraso;

b) idem, quando o débito foi submetido ao benefício do parcelamento.

A embargante confessa que efetivou o pagamento do tributo após o vencimento, embora sem pressão do Fisco. Tal circunstância é suficiente para que não seja aplicada a denúncia espontânea.

Quanto a ter existido parcelamento ou não da multa, a embargante tem razão. Ocorre que não é da multa parcelada ou não que se está tratando. A multa é uma decorrência do tributo que foi pago com atraso.

A respeito, o acórdão embargado, realmente, incidiu em interpretação errônea dos fatos. Afasto, consequentemente, esse argumento.

Mantém-se, porém, o acórdão embargado pelo primeiro fundamento: o de não se caracterizar denúncia espontânea quando o débito tributário já constituído e vencido é pago com atraso.

A configuração da 'denúncia espontânea', como consagrada no art. 138 do CTN, não tem a elasticidade pretendida, deixando sem punição as infrações administrativas pelo atraso no cumprimento das obrigações fiscais.

A extemporaneidade no pagamento do tributo é considerada como sendo o descumprimento, no prazo fixado pela norma, de uma atividade fiscal exigida do contribuinte.

É regra de conduta formal que não se confunde com o não pagamento do tributo, nem com as multas decorrentes por tal procedimento.

A responsabilidade de que trata o art. 138 do CTN, é de pura natureza tributária e tem sua vinculação voltada para as obrigações principais e acessórias àquelas vinculadas.

As denominadas obrigações acessórias autônomas não estão alcançadas pelo art. 138 do CTN. Elas se impõem como normas necessárias para que possa ser exercida a atividade administrativa fiscalizadora do tributo, sem qualquer laço com os efeitos de qualquer fato gerador do mesmo.

A multa aplicada é em decorrência do poder de polícia exercido pela administração, pelo não cumprimento de regra de conduta imposta a uma determinada categoria de contribuinte.

Por tais razões, acolho os embargos, corrijo o erro material do acórdão, porém, mantenho-o pelo primeiro fundamento apresentado e, consequentemente, a sua conclusão.

É como voto" (EDcl no REsp 573.355/RS, 1. ${ }^{a}$ T., Min. José Delgado, DJ 31.05.2004, p. 213) (grifo nosso). 
"Processual Civil. Embargos de declaração em recurso especial. Presença de omissão. Embargos de declaração acolhidos com efeitos infringentes. Denúncia espontânea. Reconhecimento. Tributo pago a destempo sem procedimento administrativo anterior e antes da entrega da DCTF referente ao imposto devido.

1. O acórdão embargado afastou o instituto da denúncia espontânea, contudo se omitiu para o fato de que a hipótese dos autos, tratada pelas instâncias ordinárias, refere-se a tributo sujeito à lançamento por homologação (IRRF), tendo o ora embargante recolhido o imposto no dia seguinte ao vencimento, antes de qualquer procedimento fiscalizatório administrativo, bem como antes da entrega da DCTF referente ao débito em questão.

2. Não tendo havido prévia declaração pelo contribuinte, configura denúncia espontânea, mesmo em se tratando de tributo sujeito a lançamento por homologação, a confissão da dívida acompanhada de seu pagamento integral, anteriormente a qualquer ação fiscalizatória ou processo administrativo. Esse é o entendimento pela Primeira Seção do STJ, ao julgar o REsp 886.462/RS, Min. Teori Albino Zavascki, DJ 28.10.2008, sob o regime do art. 543-C do CPC, que impõe sua adoção aos casos análogos como o presente.

3. Embargos de declaração acolhidos com efeitos infringentes para negar provimento ao recurso especial" (EDcl no REsp 1.055.853/PR, 2. a T., rel. Min. Mauro Campbell Marques, DJe 23.04.2009) (grifo nosso).

Mesmo na existência de súmula e de diversos acórdãos que vedam o uso da denúncia espontânea nas "obrigações acessórias autônomas", há também julgados que confirmam o benefício da denúncia espontânea em relação aos descumprimentos de deveres instrumentais à inexistência ou não de tributo decorrente do cumprimento daquele referido dever.

"Tributário. Pagamento da exação após a data de vencimento, mas antes da entrega da DCTF. Denúncia espontânea. Inteligência do art. 138 do CTN.

1. Controverte-se nos autos a respeito da configuração da denúncia espontânea na hipótese em que o tributo declarado é pago depois do vencimento. A peculiaridade é que o pagamento intempestivo ocorreu quando presentes simultaneamente as seguintes circunstâncias: a) a quitação se deu em data anterior à da entrega da DCTF, e b) inexiste qualquer outra medida de fiscalização.

2. De acordo com a disciplina conferida pelo legislador (art. 138 do CTN), não se diferencia se o tributo é sujeito ao lançamento direto (ex officio) ou por homologação. Em ambas as hipóteses, o fim social da lei - que serve de norte para a sua interpretação e aplicação - é estimular o contribuinte a se antecipar à autoridade fiscal e, assim, efetuar o recolhimento da exação mediante dispensa do pagamento da multa. 
3. Dito de outro modo, concedeu-se benefício em favor do contribuinte, por meio do qual este deixará de ser punido (não incidência da multa moratória) quando efetuar o pagamento do crédito tributário que poderia ter sido constituído, mas não o foi e não se encontra em fase de constituição.

4. A técnica arrecadatória consistente na previsão para que o cumprimento da obrigação acessória ocorra em data posterior ao da obrigação principal não tem força jurídica para revogar ou anular o instituto da denúncia espontânea.

5. Recurso especial não provido" (RE 1.025.951/PR, Min. Herman Benjamin, Dje 24.09.2010).

No referido acórdão o rel. Min. Herman Benjamin, destacou que o STJ firmou entendimento favorável à tese de que inexiste denúncia espontânea nas hipóteses em que o crédito tributário foi regularmente constituído e pago com atraso, a seguir:

"Tributário. Tributo declarado pelo contribuinte e pago com atraso. Denúncia espontânea. Não caracterização. Súmula 360/STJ.

1. Nos termos da Súmula 360/STJ: 'O benefício da denúncia espontânea não se aplica aos tributos sujeitos a lançamento por homologação regularmente declarados, mas pagos a destempo'. É que a apresentação de Declaração de Débitos e Créditos Tributários Federais - DCTF, de Guia de Informação e Apuração do ICMS - GIA, ou de outra declaração dessa natureza, prevista em lei, é modo de constituição do crédito tributário, dispensando, para isso, qualquer outra providência por parte do Fisco. Se o crédito foi assim previamente declarado e constituído pelo contribuinte, não se configura denúncia espontânea (art. 138 do (TN) o seu posterior recolhimento fora do prazo estabelecido.

2. Recurso especial desprovido. Recurso sujeito ao regime do art. 543-C do CPC e da Res. STJ 8/2008" (REsp 962.379/RS, 1. ${ }^{a}$ Seção, j. 22.10.2008, rel. Min. Teori Albino Zavascki, DJe 28.10.2008).

Por outro lado, a questão proposta, é outra, ou seja, "se há denúncia espontânea se o pagamento, ainda que intempestivo (quando considerada a data do vencimento), é realizado em momento anterior ao da entrega da DCTF, da GIA ou de documento equivalente?"

E afirmou que:

"Com efeito, de acordo com a legislação tributária, há o estabelecimento de prazos para o cumprimento da obrigação principal (vencimento do tributo a ser pago) e da obrigação acessória (entrega da declaração).

Esses prazos podem coincidir (o vencimento do tributo coincide com a data limite para entrega da declaração) ou não. Nesta segunda hipótese, as seguintes situações podem ocorrer: o tributo deve ser pago em data anterior ou posterior à entrega da declaração (...). 
Retornando à discussão travada nos autos, quando o vencimento do tributo ocorrer em data posterior à do cumprimento da obrigação acessória - e este tiver efetivamente ocorrido -, não há dúvida de que inexistirá a denúncia espontânea, pois o crédito tributário estará constituído e o Fisco dispensado da realização de qualquer atividade relacionada ao montante declarado.

Dessa forma, se o pagamento ocorrer de modo intempestivo, a multa moratória será devida.

Como proceder, contudo, na hipótese em que o vencimento do tributo for anterior ao do prazo estabelecido para cumprimento da obrigação acessória?

Nesse último caso, defende a recorrida, a caracterização da denúncia espontânea depende do confronto entre o pagamento realizado e a data da entrega da declaração.

A recorrida afirma que a jurisprudência do STJ a respeito da matéria examinou apenas a situação em que o pagamento do tributo ocorre em data posterior à da entrega da declaração (na tabela exemplificativa acima, situação 'B').

Quando o tributo for pago fora do prazo de vencimento legalmente definido, mas antes da entrega da declaração (situação 'A'), estará configurada a denúncia espontânea, pois não será possível cogitar da 'regular declaração e pagamento posterior', mas sim do 'pagamento anterior e da regular declaração'.

A Fazenda Nacional, por outro lado, afirma que é irrelevante a data da entrega da declaração. Se esta foi apresentada, o pagamento do tributo fora da data de vencimento deverá ser acrescido da multa moratória, pouco importando se realizado antes ou depois da entrega da DCTF.

Não reputo jurídica a conclusão fazendária.

Conquanto pareça confusa a questão, a verdade é que o instituto da denúncia espontânea leva em consideração apenas e tão somente um único parâmetro: a comunicação da infração, acompanhada do pagamento - se for o caso - anterior à iniciativa do Fisco.

De acordo com a Lei (art. 138 do CTN), optou-se por estimular a iniciativa do contribuinte, dispensando-o da punição (multa) relativa à intempestividade no cumprimento da obrigação tributária. É verdade que a aplicação da denúncia espontânea, nas hipóteses em que o pagamento intempestivo for realizado antes da entrega da DCTF, pode implicar a inobservância da data do vencimento do tributo, estipulada em lei. Mas, note-se, não vejo como justificar o entendimento favorável à incidência da multa moratória para um crédito tributário que nem sequer está constituído.

Em conclusão, o tratamento conferido pelo legislador não diferencia se o tributo é sujeito ao lançamento direto (ex officio) ou por homologação. Em 
ambas as hipóteses, o fim social da lei - que deve orientar a sua interpretação e aplicação - é estimular o contribuinte a efetuar o recolhimento da exação, dispensado do pagamento da multa.

Finalmente, verifico que no próprio julgamento do REsp 962.379/RS, no rito dos recursos repetitivos, essa questão foi enfrentada. Com efeito, transcrevo o seguinte excerto do voto-condutor proferido pelo eminente Min. Teori Zavascki (grifos meus):

Importante registrar, finalmente, que o entendimento esposado na Súmula 360/STJ não afasta de modo absoluto a possibilidade de denúncia espontânea em tributos sujeitos a lançamento por homologação. A propósito, reporto-me às razões expostas em voto de relator, que foi acompanhado unanimente pela $1 .^{a}$ Seção, no AgRG nos EREsp 804.785/PR, DJ 16.10.2006:

'(...) 4. Isso não significa dizer, todavia, que a denúncia espontânea está afastada em qualquer circunstância ante a pura e simples razão de se tratar de tributo sujeito a lançamento por homologação. Não é isso. O que a jurisprudência afirma é a não configuração de denúncia espontânea quando o tributo foi previamente declarado pelo contribuinte, já que, nessa hipótese, o crédito tributário se achava devidamente constituído no momento em que ocorreu o pagamento. A contrario sensu, pode-se afirmar que, não tendo havido prévia declaração do tributo, mesmo o sujeito a lançamento por homologação, é possivel a configuração de sua denúncia espontânea, uma vez concorrendo os demais requisitos estabelecidos no art. 138 do CTN. Nesse sentido, o seguinte precedente:

"Processual civil. Tributário. Agravo regimental em agravo de instrumento. Art. 545 do CPC. Recurso especial. Denúncia espontânea. CTN, art. 138. Pagamento integral do débito fora do prazo. IRRF. Tributo sujeito a lançamento por homologação. Diferença não constante da DCTF. Possibilidade de exclusão da multa moratória.

1. É cediço na Corte que 'Não resta caracterizada a denúncia espontânea, com a consequente exclusão da multa moratória, nos casos de tributos sujeitos a lançamento por homologação declarados pelo contribuinte e recolhidos fora do prazo de vencimento' (REsp 624.772/DF, 1. ${ }^{a}$ T., rel. Min. Teori Albino Zavascki, DJ 31.05.2004).

2. A inaplicabilidade do art. 138 do CTN aos casos de tributo sujeito a lançamento por homologação funda-se no fato de não ser juridicamente admissível que o contribuinte se socorra do benefício da denúncia espontânea para afastar a imposição de multa pelo atraso no pagamento de tributos por ele próprio declarados. Precedentes: REsp 402.706/SP, 1. ${ }^{a}$ T., rel. Min. Humberto Gomes de Barros, DJ 15.12.2003; AgRg no REsp 463.050/RS, 1. ${ }^{a}$ T., rel. Min. 
Francisco Falcão, DJ 04.03.2002; e EDcl no AgRg no REsp 302.928/SP, 1. ${ }^{\text {a }}$., rel. Min. José Delgado, DJ 04.03.2002.

3. Não obstante, configura denúncia espontânea, exoneradora da imposição de multa moratória, o ato do contribuinte de efetuar o pagamento integral ao Fisco do débito principal, corrigido monetariamente e acompanhado de juros moratórios, antes de iniciado qualquer procedimento fiscal com o intuito de apurar, lançar ou cobrar o referido montante, tanto mais quando este débito resulta de diferença de IRRF, tributo sujeito a lançamento por homologação, que não fez parte de sua correspondente Declaração de Contribuições e Tributos Federais.

4. In casu, o contribuinte reconhece a existência de erro em sua DCTF e recolhe a diferença devida antes de qualquer providência do Fisco que, em verdade, só toma ciência da existência do crédito quando da realização do pagamento pelo devedor.

5. Ademais, a inteligência da norma inserta no art. 138 do CTN é justamente incentivar ações como a da empresa ora agravada que, verificando a existência de erro em sua DCTF e o consequente autolançamento de tributos aquém do realmente devido, antecipa-se a Fazenda, reconhece sua dívida, e procede o recolhimento do montante devido, corrigido e acrescido de juros moratórios"”" (AgRg no AgIn 600.847/PR, 1. ${ }^{\mathrm{a}}$ T., Min. Luiz Fux, DJ 05.09.2005).

"Note-se que, na hipótese acima, o contribuinte havia declarado o débito e providenciado a sua quitação. No entanto, constatou a existência de saldo devedor, razão pela qual retificou a declaração e, concomitantemente, pagou a diferença. Em síntese, incidiu o benefício da denúncia espontânea em relação à parcela do débito não recolhida na data original, pois esta foi apurada, declarada e concomitantemente recolhida pelo contribuinte, antes de qualquer ação fiscal por parte da autoridade administrativa. Se a denúncia espontânea incide no caso do tributo recolhido concomitantemente à declaração, com maior razão estará caracterizada quando o pagamento ocorrer antes da data da constituição do crédito tributário. Em conclusão, há violação do art. 138 do CTN quando se exclui o benefício da denúncia espontânea para a hipótese de pagamento intempestivo realizado, contudo, antes da entrega da DCFT e, simultaneamente, antes de qualquer medida fiscalizatória de iniciativa da autoridade administrativa."

Desta forma, podemos notar que, segundo o entendimento do STJ, a súmula não tem aplicação absoluta, visto que, se o contribuinte não declarou, ou seja, não cumpriu o seu dever instrumental de declarar o fato, para que o crédito tributário seja constituído, caberá o benefício da denúncia espontânea. 
Tal afirmação volta na antiga discussão da concepção de base da expressão "obrigação ${ }^{8}$ acessória", que, sem ser genuína obrigação, por ausência de dimensão econômica, também nem sempre o cumprimento das condutas ali prescritas dá ensejo ao nascimento da obrigação tributária principal cujo conteúdo seja tributo, assim denominado no art. $3 .^{\circ}$ do CTN, conforme visto no item anterior.

Portanto, não havendo a declaração e, consequentemente, a constituição do crédito tributário, mediante o lançamento por homologação, o contribuinte pode até ter cometido o crime de sonegação fiscal, mas, por outro lado, também será beneficiado pela denúncia espontânea. ${ }^{9}$

Nos termos do parágrafo único do art. 138, para obter o benefício da denúncia espontânea, é requisito indispensável que o pedido seja feito antes de qualquer procedimento de ofício, ou seja, de que a mesma seja precedida de qualquer fiscalização concernente à infração.

Luciano da Silva Amaro ${ }^{10}$ interpreta este parágrafo, traçando um comparativo entre o conceito normativo do parágrafo único e o momento da conduta do agente passivo, exemplificando quanto à existência de espontaneidade:

"Se eu agir porque estou com medo do Fisco, eu estou agindo espontaneamente. Se eu agir porque a fiscalização está no meu vizinho, eu estou agindo espontaneamente. Se eu agir porque o Fisco diz que a partir de amanhã ele dará início a fiscalização - eu estou agindo espontaneamente (...)."

E continua o autor em suas exemplificações, agora quanto à falta de conduta espontânea:

8. Carvalho, Paulo de Barros. Curso de direito tributário. 18. ed. São Paulo: Saraiva, 2007. p. 303 - reúne bem os elementos da crítica à expressão "obrigação acessória". Diz o mestre: "Já no que toca à expressão do Código - obrigações acessórias - a objeção é mais abrangente. Os deveres de que falamos não têm natureza obrigacional, por faltar-lhes conteúdo dimensível em valores econômicos. E, além de não serem obrigações, nem sempre são acessórias (...). Imaginemos uma série de atos, compostos dentro de um procedimento de fiscalização, armados para certificar a ocorrência de um evento tributário. Depois de exaustivas diligências, em que o sujeito passivo se viu compelido a executar atos de informação, de comprovação, de esclarecimentos, concluem as autoridades fazendárias que não se deu o evento de que cogitavam e, portanto, não nascera a relação jurídica obrigacional".

9. Cezeroti, Guilherme. O crime de sonegação fiscal previsto no art. $2 .^{\circ}$ da Lei n. 8.137/90 e a denúncia espontânea do débito tributário. Revista Dialética de Direito Tributário 177/28-40.

10. Amaro, Luciano. Direito tributário brasileiro. 2. ed. São Paulo: Saraiva, 2008. p. 40. 
"Depois que o fiscal lavrou o termo de início de fiscalização, onde disse que vai investigar tal ou qual coisa, isso já está fora da espontaneidade. Mas qualquer outra coisa, eu continuo podendo denunciar espontaneamente. Se ele fiscalizar as minhas despesas de certa natureza, eu posso denunciar outro assunto, que não esteja dentro do escopo do que ele veio ver."11 Portanto, o contribuinte que promove a denúncia espontânea deve ser beneficiado com a exclusão de qualquer penalidade, seja ela decorrente da falta de cumprimento da obrigação principal ou acessória, uma vez que o artigo que trata sobre a matéria não faz distinção, apenas que a denúncia pode ser acompanhada do pagamento ou não, a depender da situação.

A denúncia espontânea é mecanismo normativo que permite ao sujeito passivo tributário, mesmo diante de um evento sancionatório, evitar que o fato jurídico sancionatório seja constituído pelo sujeito competente e, portanto, impedir que a constituição do descumprimento de um dever seja concretizada em nível individual e concreto.

Nesse sentido, Paulo de Barros Carvalho ${ }^{12}$ preleciona:

"Para que se tenha denúncia espontânea, necessário se faz a conjugação dos seguintes elementos:

(i) Comunicação espontânea, ao Fisco, da infração praticada;

(ii) Tratando-se de infração consistente na ausência ou insuficiência de pagamento, o recolhimento do tributo devido, acompanhado de juros de mora; e

(iii) Inexistência de procedimento administrativo ou medida de fiscalização instalados para apurar aquela ilicitude."

Robson Maia Lins ${ }^{13}$ destaca que: "em momento algum, a prestação ou não de informação do sujeito passivo ao Fisco aparece como relevante para se excluir a aplicação da denúncia espontânea".

Portanto, nos tributos sujeitos ao "autolançamento", cuja competência está prescrita no art. 150 do CTN, há plena aplicação do instituto da denúncia espontânea prevista no art. 138 do CTN. Isto porque o referido dispositivo não empresta qualquer importância ao fato de o Fisco ter conhecimento do fato jurídico tributário e da relação jurídica tributária constituída pelo contribuinte na DCTF ou GIA.

11. Idem, ibidem.

12. Direito tributário, linguagem e método. São Paulo: Noeses, 2008. p. 766-767.

13. Mora e a denúncia espontânea no direito tributário. Revista de Direito Tributário 103/91-104. 
Tanto a multa de mora quanto a multa punitiva (sancionatória), embora com nomes distintos, têm como seu pressuposto o fato jurídico "descumprir um dever jurídico", sendo o consequente o "dever de pagar de uma quantia em dinheiro". Não importa o nome: multa punitiva e multa moratória têm a mesma configuração normativa de sanção e, por isso, devem ser excluídas quando da denúncia espontânea. ${ }^{14}$

No entanto, toda esta discussão acerca da denúncia espontânea está prestes a ter um fim, em decorrência da informatização fiscal no cumprimento dos deveres instrumentais visto no item anterior.

Trataremos deste novo modelo aplicado a denúncia espontânea, demonstrando que, em um futuro próximo, o benefício da denúncia espontânea poderá ser mais utilizado pelos contribuintes.

\section{IMPACTOS DA INFORMATIZAÇÃO NA DENÚNCIA ESPONTÂNEA}

Partindo do entendimento de que, com a informatização fiscal nos deveres instrumentais, como o Sped, por exemplo, com a simples entrega das declarações, o Fisco passar a ter todas as informações necessárias para lançar de ofício, sem a necessidade de ir à empresa conferir toda a documentação, uma vez que tais documentos enviados pelo contribuinte digitalmente passaram a ser guardados no sistema do Fisco; com isto, poderemos ter mais lançamento de ofício do que por homologação, uma vez que as novas normas de informatização fiscal darão ao fisco as informações necessárias para lançar de ofício, identificando com precisão o fato jurídico e sua respectiva base de cálculo, de forma a tornar o valor devido inquestionável.

$\mathrm{Na}$ sistemática atual, o contribuinte, ao cumprir o dever instrumental de não recolher o tributo ou, até mesmo, de constituir o crédito tributário nas hipóteses prescritas em lei, a autoridade fiscal só tem condições de lançamento de ofício através do auto de infração, e, para isto, o agente fiscal tem que ir à empresa solicitar a documentação; neste caso, depende ainda da boa vontade do contribuinte em apresentar os documentos fiscais no tempo exigido, confrontar as informações que foram prestadas pelo contribuinte, para, posteriormente, efetuar o lançamento de ofício.

Neste novo cenário informatizado, ${ }^{15}$ quando o contribuinte cumprir os deveres instrumentais informatizados, entregando os documentos via digital,

14. Idem, ibidem.

15. Muito bem desenvolvido por Pinto, Fabiana Lopes. Informatização fiscal... cit. 
através de diversos mecanismos tecnológicos criados (por exemplo, o Sistema Público de Escrituração Digital que congrega a obrigatoriedade da emissão da nota fiscal eletrônica, NF-e, da escrituração fiscal digital e da escrituração contábil, além de outros mecanismos), o agente público passa a ter possibilidade de identificar o valor do tributo devido, facilitando e agilizando todo o processo de fiscalização de tributos.

Além disso, com toda esta tecnologia ligada aos deveres instrumentais e aos mecanismos de fiscalização, já se podem intuir algumas alterações substanciais, tais como o aumento da utilização do lançamento de ofício direto, a autuação fiscal on-line via certificação digital, haja vista que a maioria das informações será inquestionável, dentre vários outros.

Neste mundo informatizado, o Fisco não precisará mais visitar a empresa para conseguir fiscalizar. Basta cruzar algumas informações tecnológicas já fornecidas pelos contribuintes, apurando-se o valor exato dos tributos devidos e facilitar o processo de fiscalização. Isso torna possível reduzir a dificuldade do Fisco de identificar eventuais erros no lançamento por homologação ou encontrar os fatos não declarados e os crimes contra a ordem tributária.

E mais, neste novo modelo, há possibilidade do aumento do lançamento de ofício e/ou declaração, e futuramente os contribuintes poderão se beneficiar mais da denúncia espontânea, que atualmente se encontra limitada, uma vez que a maioria dos tributos se dá por lançamento por homologação, e, cada dia, nasce uma nova limitação para o contribuinte usufruir do benefício da denúncia espontânea, como visto no item acima.

Mas, o que estamos querendo destacar é que toda esta mudança tecnológica nos deveres instrumentais derrubará grandes questões que envolvem a denúncia espontânea atualmente, tais como: a possibilidade ou não de denúncia espontânea no chamado lançamento por homologação; no parcelamento; compensação; no dever instrumental (obrigação acessória), tema muito bem explorado por Robson Maia Lins. ${ }^{16}$

Tudo isto porque, tendo o Fisco todos os dados necessários para efetuar o lançamento de ofício, todas as informações prestadas pelo contribuinte, em cumprimento ao dever instrumental, passam a ser informações e não mais norma individual e concreta da constituição do crédito tributário. Ou seja, podemos concluir que todas estas informações prestadas ao Fisco passarão

16. Op. cit., p. 91-104. 
a ser informações para que o Fisco lance de ofício, aumentando também os tributos sujeitos ao lançamento por declaração, que atualmente se encontram extintos.

Uma vez que, não sendo informados todos os fatos para o lançamento tributário e antes que se inicie o processo de fiscalização ou medida de fiscalização instalados para apurar aquela ilicitude, o contribuinte de forma espontânea comunicar ao Fisco a infração praticada, poderá denunciar espontaneamente, sendo-lhe excluídas todas as infrações, incluindo as multas moratórias, que também têm caráter punitivo, nos casos de infração consistente na ausência ou insuficiência de pagamento, ou de recolhimento do tributo devido, acompanhado de juros de mora.

Por outro lado, com toda esta informatização, o contribuinte deverá ficar bem mais ágil no pedido de denúncia espontânea, isto porque, uma vez envidada todas as informações digitais via Internet em todas as esferas (União, Estados e Municípios), o Fisco fará a verificação, através do cruzamento de informações dadas pelo contribuinte, podendo iniciar a fiscalização mais rapidamente, notificando o contribuinte, via Internet, do início do processo de fiscalização.

Explicando melhor, com a informatização fiscal e o cruzamento de informações, ficará mais fácil e ágil ao Fisco verificar as informações prestadas e as não prestadas. Isto porque, uma vez o contribuinte estar obrigado em cumprir o dever instrumental através de arquivos digitais, automaticamente deverá gerar eletronicamente a maioria das informações fiscais que anteriormente eram encaminhadas ao Fisco em papel. Com isto, os entes políticos Federal, Estadual e Municipal terão acesso à totalidade dos dados, das notas e das obrigações ficais e contábeis de todas as empresas, por meio de documento digital de fácil utilização pela informatização fiscal para identificação do crédito tributário. Assim, o contribuinte, em querendo se beneficiar com a denúncia espontânea, deverá fazê-la o quanto antes, do contrário arcará com todas as punições previstas, por sua demora.

Todos os dados encaminhados pelos contribuintes através destes novos modelos de emissão de documento fiscal, como é o caso da nota fiscal eletrônica e cumprimento de deveres instrumentais fiscais e contábeis (Sped fiscal e contábil), poderão ser cruzados; com isto, caso haja a omissão de valores devidos a título de tributo pelos contribuintes e esta omissão for identificada pelo sistema de cruzamento de informações fiscais, o contribuinte poderá sofrer autuação fiscal e ser tipificado no de crime de sonegação fiscal. Todavia, caso venha a fazer a denúncia espontânea antes de qualquer procedimento Fisco, será beneficiado. 


\section{ConclusõES}

Podemos concluir que os novos deveres instrumentais e os mecanismos de fiscalização, instituídos com a informatização fiscal, podem vir a alterar toda a sistemática do lançamento tributário, em especial poderemos ter um aumento da utilização do lançamento por declaração e de ofício, consequentemente uma diminuição do autolançamento; o Fisco poderá notificar e até autuar o contribuinte on-line, via certificação digital; haverá diminuição na sonegação fiscal e maior utilização do benefício da denúncia espontânea, além de várias outras consequências. Isto porque, sendo todas as informações digitais e intercruzadas, passarão a ser inquestionáveis, por terem sido prestadas pelo próprio contribuinte, no cumprimento dos deveres instrumentais, ou colhidas pelos mecanismos de fiscalização.

Neste novo modelo, grande parte das questões envolvendo a denúncia espontânea, será derrubada, tendo maior aplicabilidade o art. 138 do CTN. Em contrapartida, poderão surgir novas questões ainda não regulamentadas, tais como quando se concretiza a notificação, dando início ao procedimento administrativo ou medida de fiscalização, relacionados com a infração, do envio do e-mail por parte do fisco ou da leitura do e-mail por parte do contribuinte.

\section{REFERÊNCIAS BIBLIOGRÁFICAS}

Alute, Caldas F. J. Dicionário da língua portuguesa. São Paulo: L\&PM, 2005.

Amaro, Luciano. Direito tributário brasileiro. 14. ed. São Paulo: Saraiva, 2008.

Ataliba, Geraldo. Hipótese de incidência tributária. São Paulo: Malheiros, 2004. . Noções de direito tributário. São Paulo: Ed. RT, 1971.

. Sistema constitucional tributário brasileiro. São Paulo: Ed. RT, 1968.

Imposto de Renda. Multa punitiva. Revista de Direito Administrativo. n.

126. p. 547. Rio de Janeiro, 1997.

Boвbio, Norberto. Teoria do ordenamento jurídico. 9. ed. Brasília: Ed. UnB, 1997.

Carvalho, Paulo de Barros. Curso de direito tributário. 18. ed. São Paulo: Saraiva, 2007.

Curso de direito tributário. São Paulo: Saraiva, 2008.

Direito tributário: fundamentos jurídicos da incidência. 2. ed. São Paulo:

Saraiva, 2008.

Apostila de filosofia do direito I: lógica jurídica. São Paulo: PUC, 2007.

. Apostila do curso de teoria geral do direito. São Paulo: Ibet, 2006.

Direito tributário, linguagem e método. São Paulo: Noeses, 2008.

Dınız, Maria Helena. Dicionário jurídico. São Paulo: Saraiva, 1998. vol. 4. 
Cezeroti, Guilherme. O crime de sonegação fiscal previsto no art. 2. ${ }^{\circ}$ da Lei n. 8.137/90 e a denúncia espontânea do débito tributário. Revista Dialética de Direito Tributário. n. 177. p. 28-40. São Paulo: Dialética, 2010.

Instituto Brasileiro de Direito Financeiro. Codificação do direito tributário. Rio de Janeiro: IBDF, 1955.

Kelsen, Hans. Teoria geral do direito e do Estado. São Paulo: Martins Fontes, 2000.

. Teoria geral das normas. Trad. José Florentino Duarte. Porto Alegre: Sergio Antonio Fabris Ed., 1986.

. Teoria pura do direito. São Paulo: Martins Fontes, 2006.

Lins, Robson Maia. Mora e a denúncia espontânea no direito tributário. Revista de Direito Tributário. n. 103. p. 91-104. São Paulo: Malheiros.

Machado, Hugo de Brito. Comentários ao Código Tributário Nacional - Artigos 96 ao 138. São Paulo: Atlas, 2008. vol. II.

. Curso de direito tributário. 26. ed. São Paulo: Malheiros, 2008.

. Fato gerador da obrigação acessória. Revista Dialética de Direito Tributário. n. 96. p. 31. São Paulo: Dialética, set. 2003.

Maricato, Andréia Fogaça. Deveres instrumentais: regra matriz e sanção. Dissertação de Mestrado, São Paulo, PUC, 2009.

Martins, Ives Gandra da Silva (coord.). Curso de direito tributário. São Paulo: Saraiva, 2000.

Melo, José Eduardo Soares de. Curso de direito tributário. 8. ed. São Paulo: Dialética, 2008.

Ministério da Fazenda. Trabalhos da comissão especial do Código Tributário Nacional. Rio de Janeiro, 1954.

Moraes, Bernardo Ribeiro de. Compêndio de direito tributário. 3. ed. Rio de Janeiro: Forense, 1997.

Nogueira, Ruy Barbosa. Curso de direito tributário. 15. ed. São Paulo: Saraiva, 1999.

Paulsen, Leandro. Direito tributário: Constituição e Código Tributário à luz da doutrina e da jurisprudência. 9. ed. Porto Alegre: Livraria dos Advogados, 2007.

Peixoto, Marcelo Magalhães; Lacombe, Rodrigo Santos Masset (coords.). Comentários ao Código Tributário Nacional. São Paulo: MP Ed., 2005.

PInTo, Fabiana Lopes. Impacto financeiro da sonegação fiscal-penal. Disponível em: [www.lopespinto.com.br/adv/publier4.0/dados/anexos/617_4.ppt]. Acesso em: 15.02.2012.

Informatização fiscal: o uso da tecnologia no sistema tributário nacional. Tese de Doutorado, São Paulo, PUC, 2012.

Pontes de Miranda, Francisco Cavalcanti. Comentários da Constituição de 1967. São Paulo: Ed. RT, 1970. 
SAnti, Eurico Marcos Diniz de. Lançamento tributário. São Paulo: Max Limonad, 2001.

SousA, Rubens Gomes de. Anteprojeto de Código Tributário Nacional. Rio de Janeiro: Departamento de Imprensa Nacional, 1953.

. Compêndio de legislação tributária - Parte geral. 3. ed. Rio de Janeiro: Financeiras, 1964.

; Ataliba, Geraldo; Carvalho, Paulo de Barros. Comentário ao Código Tributário Nacional. São Paulo: Ed. RT, 1975.

Tomé, Fabiana Del Padre. A prova no direito tributário. São Paulo: Noeses, 2005.

Vilanova, Lourival. Causalidade e relação no direito. 4. ed. São Paulo: Ed. RT, 2000.

As estruturas lógicas e o sistema do direito positivo. 3. ed. São Paulo: Noeses, 2005.

. Sobre o conceito do direito. Recife: Imprensa Oficial, 1947.

\section{Pesouisas do Editorial}

\section{Veja também Doutrina}

- A nota fiscal eletrônica e sua validade juridica como meio de prova no processo civil tributário, de Leila Von Söhsten Ramalho e Flávia Almeida Pita - RTrib 86/153;

- Denúncia espontânea em direito tributário, de Marcus de Freitas Gouvêa - RTrib 64/40; e

- Denúncia espontânea: pressupostos de admissibilidade, requisitos de forma e impossibilidade de alteração do instituto pelas entidades tributantes, de Felipe Luiz Machado Barros - RTrib 49/145. 